IZA DP No. 6136

R\&D Drivers in Young Innovative Companies

José García-Quevedo

Gabriele Pellegrino

Marco Vivarelli

November 2011 


\title{
R\&D Drivers in Young Innovative Companies
}

\author{
José García-Quevedo \\ University of Barcelona \\ Gabriele Pellegrino \\ University of Barcelona \\ and Università Cattolica del Sacro Cuore \\ Marco Vivarelli \\ Università Cattolica del Sacro Cuore, \\ SPRU, University of Sussex and IZA
}

\section{Discussion Paper No. 6136 \\ November 2011}

\author{
IZA \\ P.O. Box 7240 \\ 53072 Bonn \\ Germany \\ Phone: +49-228-3894-0 \\ Fax: +49-228-3894-180 \\ E-mail: iza@iza.org
}

\begin{abstract}
Any opinions expressed here are those of the author(s) and not those of IZA. Research published in this series may include views on policy, but the institute itself takes no institutional policy positions.

The Institute for the Study of Labor (IZA) in Bonn is a local and virtual international research center and a place of communication between science, politics and business. IZA is an independent nonprofit organization supported by Deutsche Post Foundation. The center is associated with the University of Bonn and offers a stimulating research environment through its international network, workshops and conferences, data service, project support, research visits and doctoral program. IZA engages in (i) original and internationally competitive research in all fields of labor economics, (ii) development of policy concepts, and (iii) dissemination of research results and concepts to the interested public.
\end{abstract}

IZA Discussion Papers often represent preliminary work and are circulated to encourage discussion. Citation of such a paper should account for its provisional character. A revised version may be available directly from the author. 
IZA Discussion Paper No. 6136

November 2011

\section{ABSTRACT}

\section{R\&D Drivers in Young Innovative Companies}

This paper examines the determinants of young innovative companies' (YICS) R\&D activities taking into account the autoregressive nature of innovation. Using a large longitudinal dataset comprising Spanish manufacturing firms over the period 1990-2008, we find that previous R\&D experience is a fundamental determinant for mature and young firms, albeit to a smaller extent in the case of the YICs, suggesting that their innovation behaviour is less persistent and more erratic. Moreover, our results suggest that firm and market characteristics play a distinct role in boosting the innovation activity of firms of different age. In particular, while market concentration and the degree of product diversification are found to be important in fostering R\&D activities in the sub-sample of mature firms only, YICs' spending on R\&D appears to be more sensitive to demand-pull variables, suggesting the presence of credit constraints. These results have been obtained using a recently proposed dynamic type-2 tobit estimator, which accounts for individual effects and efficiently handles the initial conditions problem.

JEL Classification: $\quad 031$

Keywords: $\quad$ R\&D, innovation, Young Innovative Companies (YICs), dynamic type-2 tobit estimator

Corresponding author:

Marco Vivarelli

Università Cattolica del Sacro Cuore

Facoltà di Economia

via Emilia Parmense 84

29100 Piacenza

Italy

E-mail: marco.vivarelli@unicatt.it

\footnotetext{
* We are very grateful to Pere Arqué for his help regarding many aspects of this paper and to Daniel Montolio and Mariacristina Piva for their useful comments. We also wish to thank the SEPI Foundation for providing the data. A previous version of this paper was presented at the Conference on Corporate R\&D, CONCORD 2011 (European Commission-JRC-IPTS, Seville, Spain; October, 6, 2011).We are grateful for all the comments from participants and particularly to Bronwyn H. Hall. José GarciaQuevedo and Gabriele Pellegrino gratefully acknowledge support from the Spanish Ministry of Science and Education (ECO2010-16934). José Garcia-Quevedo is also grateful for support from the Generalitat de Catalonia (2009SGR102). The usual caveat applies.
} 


\section{Introduction}

The analysis of the determinants of a firm's R\&D activity is a classic concern of the Economics of Innovation, dating from the seminal contribution by Griliches (1979) (see also Griliches, 1994 and 1996). More recently, endogenous growth models have singled out human capital and its accumulation through education and knowledge as the main sources of long-term economic growth (see Mankiw et al., 1992; Romer, 1994; Lucas, 2002). In this respect, several studies state that $R \& D$ investment represents the main engine of technological progress and economic growth (see Nelson and Winter, 1982; Mansfield, 1988; Aghion and Howitt, 1998).

Interest in the field has been reawakened following recent reports that identify the essential role played by a specific type of firm - the so-called Young Innovative Companies (YICs) ${ }^{1}-$ in the renewal of the industrial structure and in contributing to aggregate economic growth. Baumol et al. (2007), for instance, point out that, over the last 15 years, productivity growth in advanced economies has been due in the main to the development of innovative entrepreneurial companies, such as Microsoft, Intel, eBay, Amazon, Google, Apple, among others.

In seeking to account for the persistent gap that exists between the EU and the US in terms of innovative performance and productivity, scholars and policy makers often refer to weaknesses regarding YICs. Indeed, in Europe, young companies have lower capacities to innovate and higher rates of early failure (see Bartelsman et al., 2004; Santarelli and Vivarelli, 2007), whereas the US economy has been able to generate a steadily increasing flow of YICs that not only survive but which develop new products at the core of emerging sectors. For these reasons, many EU countries have implemented policies to support the creation and growth of YICs, focusing - for instance - on facilitating their access to funding and providing support for the commercialization of innovation (see EC-DG ENTER, 2009; Schneider and Veugelers, 2010).

\footnotetext{
${ }^{1}$ According to the European Commission's State Aid rules, Young Innovative Companies are defined as small companies, less than six years old, 'certified' by external experts on the basis of a business plan as capable of developing products or processes which are new or substantially improved and which carry a risk of technological or commercial failure, or have R\&D intensity of at least $15 \%$ in the last three years or current year (for start-ups).
} 
Despite this policy concern, few studies have explicitly examined the specific characteristics of YICs and their contribution to Europe's innovative performance. Moreover, little evidence has been gathered on a number of important issues that could have major policy implications. What, for example, are the factors that might lead a young firm to engage in $R \& D$ ? Are there substantial differences in the factors that affect the level of R\&D investment in YICs, on the one hand, and mature firms, on the other? Is the $R \& D$ process equally persistent in firms of different ages?

By drawing on a large longitudinal dataset of Spanish manufacturing firms, the objective of this paper - and its main novelty - lies in the assessment we make of the differences that exist between firms of different ages in terms of the drivers that increase the probability of their engaging in R\&D activity, on the one hand, and those that determine the intensity of this activity, on the other. A recently proposed dynamic type2 tobit model (Raymond et al., 2010) is applied to perform the microeconometric analysis.

The remainder of the paper is organised as follows. Section 2 provides a brief review of previous studies on the determinants of $R \& D$. In Section 3 we present the hypotheses that will be tested. Section 4 provides a discussion of the econometric methodology adopted. In Section 5 we present the data and the variables used in the empirical analysis. The estimation results are discussed in Section 6, while in Section 7 the main conclusions and findings of the study are briefly summarised.

\section{The literature}

The first author to conduct a theoretical analysis of the drivers of $R \& D$ activities was Joseph Schumpeter. In “Capitalism, Socialism and Democracy” (Schumpeter, 1942), the Austrian scholar claims: 'The atomistic firm operating in a competitive market may be a perfectly suitable vehicle for static resource allocation, but the large firm operating in a concentrated market is the most powerful engine of progress and ... long-run expansion of total output'. This simple statement has inspired a vast and well- 
established body of literature, both theoretical and empirical, which has - with some exceptions - confirmed Schumpeter's predictions (the so-called "Schumpeterian hypothesis") that the size of the company and the degree of market concentration are direct determinants of innovation activity. In this line, several studies note, firstly, that larger firms are more likely to undertake R\&D activity as they are not affected by liquidity constraints (i.e. they enjoy easier access to external finance and larger internal funds; see Cohen and Klepper, 1996; Mairesse and Mohnen, 2002; Conte and Vivarelli, 2005); secondly, that firms with greater market power have greater incentives to innovate because they can better appropriate returns from their $R \& D$ investments (see Gilbert and Newbery, 1982; Blundell et al., 1999).

A further important stream of literature related to the drivers of innovation activity is represented by the demand-pull vs technology-push debate. Since Schmookler's (1962) seminal contribution, many authors have tested the hypothesis that demand drives the rate and direction of innovation. In this line, various theoretical and empirical approaches, both at the aggregate (see Schmookler, 1966; Scherer 1982; Kleinknecht and Verspagen, 1990; Geroski and Walters, 1995) and at the microeconomic level (see Brouwer and Kleinknecht, 1996, 1999; Piva and Vivarelli, 2007) converged to consider demand and market growth as essential factors for boosting innovation activity based on increasing returns of scale, optimistic expectations and diminishing cash constraints.

The first comprehensive discussion of the technology-push hypothesis was put forward by Mowery and Rosenberg (1979). The core idea is that the rate and direction of technological change is basically affected by advances in science and technology and by the availability of exploitable 'technological opportunities' (see Klevorick et al., 1995). Subsequent studies extended this notion stressing the key role to be played by cumulated knowledge investment in fostering firms' 'absorptive capacity', that is their ability to exploit external technological opportunities (see Mowery, 1983; Pavitt, 1984; Cohen and Levinthal, 1989 and 1990; Rosenberg, 1990; Rosenberg, 1994).

In essence, the technology-push theory holds that R\&D activities are dependent on their own rules of development. Thus, within a firm, R\&D activities are highly localized (Atkinson and Stiglitz, 1969) and path-dependent (see Rosenberg, 1982; David, 1985). Closely related to these concepts, is the idea of a dominant 'technological trajectory' 
according to which innovation, and in particular R\&D activities, are processes that show high degrees of cumulativeness and irreversibility and, as a result, are characterised by a higher level of persistence (see Dosi, 1988). These considerations open up the way to a dynamic first order autoregressive [AR(1)] specification of firms' decisions regarding both whether or not to engage in $R \& D$ and how much to invest in R\&D activities.

However, as Dosi (1988 and 1997) points out, patterns of technical change are the result of the interaction between different types of market incentives, on the one hand, and technological opportunities, on the other. Working within this framework, most recent empirical studies tend to take both demand-pull and technology-push theories into account (see Crépon et al., 1998, Mohnen and Dagenais, 2002).

Moreover, in order to provide a more realistic and comprehensive analysis of a firm's innovation process, the specific features of a given company need to be considered. Thus, thanks in part to the availability of more detailed innovation surveys, in recent years various authors have reported more accurate empirical analyses, providing vital evidence about the role that endogenous firm characteristics may have in stimulating/hindering R\&D activities. The remainder of this section undertakes a brief discussion of the main results emerging from this more recent strand of literature.

For instance, many recent studies have devoted their attention to the analysis of the impact of R\&D subsidies. Most of them (see for example Callejon and García-Quevedo, 2005; González et al., 2005 for the Spanish case) have provided empirical evidence that is moderately supportive of the positive effect of government subsidies in stimulating R\&D activities. However, some contributors (see, for example, Wallsten, 2000) have questioned these results on the grounds that very few studies explicitly consider the potential endogeneity of public funding.

Reverse causation has also been detected in the relationship between $R \& D$ and exports. Specifically, two different mechanisms can characterise this relationship. On the one hand, there is the possibility of 'learning by exporting': exporters, through interaction with foreign agents, can exploit knowledge inputs not available to domestic firms, enhance their competences and consequently be more likely to invest in R\&D activities (see Melitz, 2003; Yeaple, 2005; Cassiman et al., 2010). On the other hand, some 
authors (see, for example, Clerides et al., 1998) have highlighted the possibility of the emergence of a self-selection mechanism: most innovative firms are more likely to penetrate foreign markets and self-select themselves so as to engage in tougher foreign competition. Given these two quite distinct explanations, an analytical framework is required to properly deal with this endogeneity issue.

A further firm characteristic that has been demonstrated to have a positive effect on the propensity of a firm to engage in $R \& D$ is its degree of product diversification. Here, economic theory notes a close relationship between scope economies and R\&D activity: a firm with a diversified portfolio of products can benefit from potential internal knowledge spillovers and so be better positioned to understand the applicability of new ideas (Henderson and Cockburn, 1996).

Piva and Vivarelli (2009) claim that higher manpower skills may also result in higher levels of R\&D investment. Indeed, skilled workers, in comparison with their unskilled counterparts, are: 1) more suited to dealing with complexity - a prominent characteristic of innovation (Song et al., 2003); 2) more likely to 'absorb' knowledge and consequently to reinforce the absorptive capacity of a given organization (Cohen and Levinthal, 1990); 3) more successful in exploiting innovative ideas.

\section{Hypotheses to be tested}

As discussed in the introduction, the purpose of this paper is to identify any differences that might exist between young and mature firms in terms of the factors that stimulate the probability of their engaging in R\&D activity and those that determine the intensity of this investment. Specifically, and bearing in mind the discussion presented in the previous section, we propose the following two research questions:

- Do YICs show the same degree of sensitivity to certain drivers as that shown by their mature counterparts, when deciding whether to engage in $R \& D$ activities and when choosing how intensively they wish to invest in R\&D? 
- Furthermore, is innovation in YICs less persistent than it is in their mature counterparts?

It is not an easy task to identify specific theoretical predictions concerning these questions. Indeed, to the best of our knowledge, no previous studies have examined the R\&D drivers in YICs, although there is some evidence of the role of a firm's age in determining the decision to engage in R\&D activities and in enhancing its investment in R\&D. ${ }^{2}$ However, some hypotheses can be derived from the related streams of literature discussed in the previous section.

An initial source of the differences manifested by firms of different ages might well be related to the impact that financial and liquidity constraints have in determining a firm's decision to engage in R\&D. Clearly, a lack of finance is a major hindrance to innovation and investment in R\&D activities. In this regard, there is a vast body of empirical literature highlighting the relative advantage enjoyed by large firms (Beck and Demirgüç-Kunt, 2006; Czarnitzki, 2006). Hall (2008), for example, suggests that small firms are more likely to be affected by imperfections in capital markets than are large firms, since the former can rely less on internal funds.

By contrast, less attention has been given to the differences - in terms of financial constraints affecting the investment in $R \& D$ - between mature and young firms (Cincera, 2003; Czarnitzki and Hottenrott, 2011). Yet, there are various reasons why YICs should be more sensitive to such constraints than are their mature counterparts. Firstly, young firms typically have yet to develop a reputation and their sources of collateral are scarce - two factors that are important in mitigating capital market imperfections. Secondly, they can rely less on internal funds since accumulated past profits are scarce by definition. ${ }^{3}$ Here, for example, Fluck et al. (1997) report that the ratio of external finance to total finance tends to fall once a firm has been operating for more than seven or eight years, while Reid (2003) provides evidence of an inverse relationship between a firm's age and its debt ratio. Thirdly, in contrast with mature firms, newly founded entities do not have recourse to an established, long-term

\footnotetext{
${ }^{2}$ A positive relationship between a firm's age and the probability of engaging in R\&D is found in both Artés (2009) and Ortega-Argilés et al. (2005) for the Spanish case.

${ }^{3}$ Note that mergers and acquisitions are excluded from the definition of YICs.
} 
relationship with banks (Petersen and Rajan, 1995; Martinelli, 1997; Berger and Udell, 2002). By the same token, as Fritsch et al. (2006) point out, bank financing of the R\&D projects of young firms might be more limited given the higher risks of default. Finally, established companies can base their innovative activity on past successes, concentrating their attention - for example - on product differentiation or improvement, whilst YICs might be forced to undertake more fundamental R\&D investments which may prove to be more costly and uncertain.

The above discussion points to a negative relationship between a firm's age and liquidity constraints, suggesting that young firms should be more sensitive than their mature counterparts to some R\&D drivers. More specifically, the following hypotheses can be drawn:

H1: Since YICs may be affected by liquidity constraints and possible credit rationing, they attach greater importance than do their mature counterparts to current sales and internal cash flow when deciding to invest in R\&D activities. ${ }^{4}$

H2: Since exports are a key component of demand evolution, YICs should show higher innovation/export elasticity.

H3: Similarly, YICs should be more sensitive to the amount of subsidies received as these represent an alternative source for financing their R\&D projects.

A further characteristic that can play a role in differentiating mature from young firms is obviously their degree of experience. An essential part of this experience is represented by the learning process (Arrow, 1962). However, this concept can be considered more broadly and, in particular, as a cumulative improvement in the stock of knowledge within a given firm. Thus, experience and the learning process can be essential in increasing a firm's innovative capability and absorptive capacity over time: learning in one period will render more efficient the process of accumulation of knowledge in the subsequent period. By definition, this path-dependent pattern should be more obvious in

\footnotetext{
${ }^{4}$ Evidence of the greater importance of current sales in determining the innovation decision of financially constrained firms can be found in Goodacre and Tonks (1995), Hall et al. (1999), O’Sullivan (2005) and Piva and Vivarelli (2007).
} 
mature, well-established firms than in inexperienced YICs. Thus, we can put forward the following hypothesis:

H4: Given their relative inexperience, the innovative processes of YICs should follow a more erratic path and be less persistent.

A firm's experience and capacity to absorb knowledge are also important in determining the magnitude of the impact on a firm's innovation activity through the exploitation of economies of scope:

H5: Well-established firms, being characterized by a larger scale and greater experience and absorptive capacity, are in a better position to take advantage of economies of scope. Accordingly, product diversification is expected to be a more important $R \& D$ driver for mature innovative firms than for YICs.

In line with the arguments presented above, the availability of advanced skills is one of the main ways in which a young firm can compensate for its lack of experience and its limited absorptive capacity; therefore:

H6: Given their lower level of experience and absorptive capacity, YICs should be more dependent on their own skill endowment as an internal driver of R\&D investment.

Finally, appropriability conditions can be expected to be much more relevant $R \& D$ drivers for mature, larger incumbents than they are for young, small newcomers (see Acs and Audretsch, 1988 and 1990; Audretsch, 1997). Hence, the following hypothesis can be forwarded:

H7: The degree of market concentration should be more important in stimulating the innovation activity of mature firms than in stimulating that of their younger counterparts.

\section{Econometric methodology}

Following Artes’ (2009) approach, we model an R\&D firm’s decision-making process by distinguishing between long- and short-run strategies. Specifically, we assume that 
the long-run, or strategic choice involves deciding whether to engage in $R \& D$ activity or not, while the short-run decision concerns how much to invest in R\&D. Formally, we have:

$$
\begin{aligned}
& d_{i t}=1\left[\rho d_{i, t-1}+\delta^{\prime} Z_{i t}+\alpha_{1 i}+\varepsilon_{1 i t}>0\right] \\
& \gamma_{i t}=\left\{\begin{array}{cc}
\partial \gamma_{i, t-1}+\beta^{\prime} X_{i t}+\alpha_{2 i}+\varepsilon_{2 i t} & \text { if } d_{i t}=1 \\
0 & \text { if } d_{i t}=0
\end{array}\right.
\end{aligned}
$$

Equation (1) is the selection equation and it models the long-run decision of enterprise $i$ to invest in R\&D activities as a latent function of its past R\&D decision $\left(d_{i, t-1}\right)$, strictly exogenous explanatory variables $\left(Z_{i t}\right)$, time-invariant unobserved individual effects $\left(\alpha_{1 i}\right)$ and an idiosyncratic error term $\left(\varepsilon_{1 i t}\right)$. If the incentive to invest in R\&D (expression in brackets) is larger than zero, firms $i$ can be defined as innovative.

The main equation (2) models the short-run decision of innovator $i$ (conditional on: $\left.d_{i t}=1\right)$ as a function of its past R\&D investments $\left(\gamma_{i, t-1}\right)$, its characteristics $\left(X_{i t}\right)$, time-invariant unobserved individual effects $\left(\alpha_{2 i}\right)$ and an idiosyncratic error term $\left(\varepsilon_{2 i t}\right)$ independent of $X_{i t}$.

The dynamic nature of these two equations, together with the fact that equation (2) can only be observed for those firms that invest in $R \& D$ activities, leads us to employ an econometric methodology based on the application of a dynamic type-2 tobit model.

To estimate such a model, we must first solve two problems, namely: 1) the presence of unobserved individual effects; 2) the correlation between the initial conditions and the individual effects. The latter problem occurs because the first observation for each firm referring to a dynamic variable (initial condition) is determined by the same data generation process, and so it turns out to be correlated with both the individual error term and the future realizations of the variable.

In order to deal jointly with these problems, we use the methodology proposed by Raymond et al. (2010). First, we assume the individual error terms, $\alpha_{1 i}$ and $\alpha_{2 i}$, have a 
joint distribution and we apply a random-effects approach. Second, we treat the initial conditions problem in line with Wooldridge (2005), and assume that the unobserved individual effects depend on the initial conditions and the strictly exogenous variables:

$$
\begin{aligned}
& \alpha_{1 i}=b_{1}^{0}+b_{1}^{1} d_{i 0}+b_{1}^{\prime 2} Z_{i}+u_{1 i} \\
& \alpha_{2 i}=b_{2}^{0}+b_{2}^{1} \gamma_{i 0}+b_{2}^{\prime 2} X_{i}+u_{2 i}
\end{aligned}
$$

where $b_{1}^{0}$ and $b_{2}^{0}$ are constants, $d_{i 0}$ and $\gamma_{i 0}$ are the initial values of the dependent variables and $Z_{i}$ and $X_{i}$ are Mundlak within-means (1978) of $Z_{i t}$ and $X_{i t}$. The vectors $\left(\varepsilon_{1 i t}, \varepsilon_{2 i t}\right)$ and $\left(u_{1 i}, u_{2 i}\right)$ are assumed to be independently and identically (over time and across individuals) normally distributed with means 0 and covariance matrices, equal to:

$$
\Omega_{\varepsilon 1 \varepsilon 2}=\left(\begin{array}{cc}
1 & \rho_{\varepsilon_{1} \varepsilon_{2}} \sigma_{\varepsilon_{2}} \\
\rho_{\varepsilon_{1} \varepsilon_{2}} \sigma_{\varepsilon_{2}} & \sigma_{\varepsilon_{2}}^{2}
\end{array}\right) \text { and } \Omega_{u 1 u 2}=\left(\begin{array}{cc}
\sigma_{u_{1}}^{2} & \rho_{u_{1} u_{2}} \sigma_{u_{1}} \sigma_{u_{2}} \\
\rho_{u_{1} u_{2}} \sigma_{u_{1}} \sigma_{u_{2}} & \sigma_{u_{2}}^{2}
\end{array}\right)
$$

Hence, the likelihood function of a given firm $i$, starting from $t=1$ and conditional on the regressors and the initial conditions, can be written as:

$$
L_{i}=\int_{-\infty}^{\infty} \int_{-\infty}^{\infty} \prod_{t=1}^{T} L_{i t}\left(d_{i t}, \gamma_{i t} \mid d_{i 0}, d_{i, t-1}, Z_{i}, \gamma_{i 0}, \gamma_{i, t-1}, \mathrm{X}_{i}, u_{1 i}, u_{2 i}\right) g\left(u_{1 i}, u_{2 i}\right) d u_{1 i} d u_{2 i}
$$

where $\prod_{t=1}^{T} L_{i t}\left(d_{i t}, \gamma_{i t} \mid d_{i 0}, d_{i, t-1}, Z_{i}, \gamma_{i 0}, \gamma_{i, t-1}, \mathrm{X}_{i}, u_{1 i}, u_{2 i}\right)$ represents the likelihood function once the individual effects have been integrated out and can be treated as fixed, and $g\left(u_{1 i}, u_{2 i}\right)$ is the bivariate normal density function of $\left(u_{1 i}, u_{2 i}\right)^{\prime}$. 
Therefore, equations (1) and (2) are jointly estimated by using the maximum likelihood estimator and are correlated through the individual effects $\left(\rho_{u_{1} u_{2}} \neq 0\right)$ and the idiosyncratic error terms $\left(\rho_{\varepsilon_{1} \varepsilon_{2}} \neq 0\right)$. The 'total' correlation between the two equations ${ }^{5}$ being:

$$
\rho_{\text {tot }}=\frac{\rho_{u_{1} u_{2}} \sigma_{u_{1}} \sigma_{u_{2}}+\rho_{\varepsilon_{1} \varepsilon_{2}} \sigma_{\varepsilon_{2}}}{\sqrt{\left(\sigma_{u_{1}}^{2}+1\right)\left(\sigma_{u_{2}}^{2}+\sigma_{\varepsilon_{2}}^{2}\right)}}
$$

\section{Dataset and variables}

The data used in this work are drawn from the Survey on Business Strategies (Encuesta Sobre Estrategias Empresariales, henceforth ESEE) which has been conducted yearly since 1990 by the SEPI foundation (formerly the Fundaciíon Empresa Pública), on behalf of the Spanish Ministry of Industry. The annual survey comprises extensive information on around 2,000 companies, with a particular focus on technological activity and the main characteristics of the market in which each firm operates. ${ }^{6}$ The sampling procedure ensures representativeness for each two-digit NACE manufacturing sector, following both exhaustive and random sampling criteria. Specifically, in the first year of the survey all Spanish manufacturing firms with more than 200 employees were required to participate (715 in 1990), and a sample of firms employing between 10 and 200 workers were selected using a stratified, proportional, restricted and systematic sampling method with a random start (1,473 firms in 1990). In order to guarantee a high level of representativeness and to preserve the inference properties, newly created companies have been incorporated in the survey every year according to the same criteria. In this way, both the sample of respondent firms with fewer than 200 workers and more than 10 (rate of response around 4\%) and the sample of respondent firms

\footnotetext{
${ }^{5}$ The lower panel of Table 6 reports the estimates of the extra parameters included in (6).

6 For a more detailed description of the database see http://www.funep.es/esee/en/einfo_contiene.asp.
} 
employing more than 200 workers (rate of response around 60\%) are representative of Spanish industry. ${ }^{7}$

In this study, we consider survey data for the period 1990 to 2008. The original sample comprised 34,849 observations, but because of missing variables and the fact that some firms underwent mergers and acquisitions, ${ }^{8}$ we ended up with an unbalanced panel of 21,706 observations. Table 1 shows the composition of this unbalanced panel according to the number of years a given firm is observed. As can be seen, around $59 \%$ of the 3,489 firms included in the final sample were observed for fewer than seven years. The remaining $41 \%$ were observed for at least seven years and a far from negligible percentage (around 25\%) were observed for more than ten years.

\section{$<$ INSERT TABLE $1>$}

Given the specific aim of this study, we needed to establish an age threshold so as to divide the full sample into young and mature firms. We opted for eight years, in order to obtain a good degree of representativeness in the sub-sample of young firms, albeit without increasing the age threshold too far. ${ }^{9}$ Table 2 shows the size of the two subsamples of mature and young companies, according to their innovative status. As can be seen, about $33 \%$ of the total sample of firms engage in $R \& D$ (both internal and external), whereas only $21 \%$ of the 1,168 firms aged eight years or less engage in R\&D activities. Hence, the proportion of R\&D performers increases with the age of the firm.

\section{$<$ INSERT TABLE $2>$}

Table 3 shows the transition probabilities of engaging in $R \& D$ activities or otherwise during the period analysed, distinguishing between mature and young firms. Unsurprisingly, innovation is highly persistent, while transitions are very rare. Nearly

\footnotetext{
${ }^{7}$ Several studies provide evidence of the representativeness of ESEE for Spanish industry (see, among others, González et al., 2005; Lopez, 2008).

${ }^{8}$ These firms were eliminated from the sample in the years following the merger or acquisition.

${ }^{9}$ Robustness checks were performed assuming alternative thresholds of nine and ten years. Our results - available upon request - are consistent (both in terms of the sign and statistical significance of the estimated coefficients) with those discussed in Section 6. In contrast, convergence problems prevented us from running robustness checks for thresholds lower than eight years, because of the paucity of observations within the sub-sample of young firms.
} 
$88 \%$ of $R \& D$ performers in one period persisted in this activity during the following year, with just $12 \%$ interrupting their innovative activities. By the same token, roughly $94 \%$ of non R\&D performers maintained this status into the subsequent period while just 6\% initiated innovation activities. Interestingly, less persistence is observed in the sub-sample of young firms; in fact, only $81 \%$ of young R\&D performers in one period maintained this status into the next period.

\section{$<$ INSERT TABLE 3 >}

\subsection{Variables}

In line with the econometric methodology described in Section 4, two dependent variables are considered for the dynamic equations: a dummy variable that takes a value of 1 if $R \& D$ expenditures (both internal and external) are greater than 0 is used in equation (1); and the natural logarithm of R\&D expenditures as a measure of a firm's innovative effort is used in equation (2). The covariates are then selected according to the theoretical discussion advanced in Section 2 and the seven hypotheses proposed in Section 3.

The rationale underlying the strategy adopted in differentiating between the two estimated equations is linked to the time horizon of the firm's R\&D decisions. ${ }^{10}$ In other words, it is plausible that some factors are only important in determining a firm's longrun decision (equation 1), while others are relevant in both cases (equations 1 and 2).

In the case of those factors that only affect a firm's decision as to whether or not to engage in $R \& D$, we have introduced two dummy variables: the 'CONC' variable that indicates whether a firm operates in a highly concentrated market (with fewer than 10 competitors); the 'DIVER' variable which identifies firms with greater product diversification. Our decision to include these variables in the selection equation only is based on their discrete nature and on the fact that they depict firm or market

\footnotetext{
10 The decision to distinguish between the two equations was undertaken exclusively on theoretical grounds. In fact, given that the econometric methodology used here is based on a fully parametric approach, there are no exclusion restrictions in the vectors of what are strictly exogenous explanatory variables. This means that $Z_{i t}$ in equation (1) and $X_{i t}$ in equation (2) may be the same, completely different or they may have common explanatory variables (see Raymond et al., 2010).
} 
characteristics which are highly persistent over time. Therefore, it is plausible to think that these structural features may affect a firm's long-run decision to undertake R\&D activities or not.

In the case of the regressors that are included in both equations, we first sought to verify the demand-pull hypotheses $\mathrm{H} 1, \mathrm{H} 2$ and $\mathrm{H} 3$ by considering a dummy variable, 'DYNAM'11 - that takes a value of 1 if the main market in which the firm operates is expansive - and two continuous variables: 'LEXP_1'and 'LSUB_1' that record, respectively, the value of the firms' exports and the total amount of subsidies received by the firms (both in logs). In order to avoid possible problems of endogeneity, we have considered the one period lagged value of both the continuous variables. ${ }^{12}$

A further factor that might prove to be important in determining both decisions is represented by the 'SKILL' variable (see hypothesis H6). This measures the proportion of skilled employees (engineers and graduates) within a firm.

Finally, the log of employees is included in both equations, in order to control for firm size (“Schumpeterian hypothesis”).

Table A1 in the Appendix describes the variables used in the empirical analyses, while Table 4 reports the corresponding descriptive statistics, distinguishing between the total sample, mature and young firms. ${ }^{13}$

\section{$<$ INSERT TABLE 4>}

\footnotetext{
${ }^{11}$ In principle, it would have been better to consider a continuous variable measuring a firm's total sales; however, to avoid multicollinearity due to the high correlation between this variable and the LEXP_1 variable $(\rho=0.75)$, we opted in favour of a dummy variable.

${ }^{12}$ In fact, as discussed in Section 2, it may well be the case that innovative firms are more likely to receive public subsidies and to enter foreign markets.

${ }^{13}$ As can be seen, for most the explanatory variables the between variation (across firms) is much higher than the within variation (time variation). This trait, which is very common in firm-level datasets, means the variables are strongly correlated with their Mundlak or within means (see Table A2 in the Appendix). Thus, to avoid problems of multicollinearity between the variables and their within means (which might bias the results of the main estimations), we followed the strategy adopted by Raymond et al. (2010, FN 8, p. 500) and we assumed the individual error terms to be correlated only with the initial values of $d_{i t}$ and $\gamma_{i t}$.
} 
Table 5 shows sectoral composition and firm's average size of the total sample and distinguishes between young and mature firms. As can be seen, no striking sectoral differences emerge; however, to control for any particular industry-specific market and technological factors that might affect a firm's propensity to engage in $R \& D$ activities, a set of industry dummies was included in all the regressions (19 two-digit dummies).

As expected, young firms are systematically smaller than their mature counterparts (on average 103 vs 228 employees). This confirms that firms' size increase with age. As mentioned above, in order to ensure that the results of the analysis are not affected by any potential scale effect, we included in both equations the 'LEMP' variable, which measures the logarithm of the total number of employees in a firm.

Finally, all the estimates were checked for time dummies, in order to take into account possible macroeconomic and cyclical effects.

\section{$<$ INSERT TABLE $5>$}

\section{Results}

Table 6 reports the econometric results of the dynamic panel data type-2 tobit model applied to the whole sample and independently to the two sub-samples of mature and young firms. Specifically, the top part of the table shows the estimates of the equation (1) parameters; the middle section of the table shows the estimation results of the equation (2) parameters; while the bottom section reports the coefficients of the initial conditions $\left(d_{i 0}, y_{i 0}\right)$, the cross-equation correlations $\left(\rho_{u_{1} u_{2}}, \rho_{\varepsilon_{1} \varepsilon_{2}}\right)$ and the standard deviations of the error terms $\left(\sigma_{u_{1}}, \sigma_{u_{2}}, \sigma_{\varepsilon_{2}}\right)$. 
As can be seen from the bottom section of Table 6, the initial conditions are highly relevant and the two equations are highly correlated via the individual effects and the cross-equation correlation. ${ }^{14}$ Furthermore, the high level of significance of the coefficients of $\sigma_{u 1}$ and $\sigma_{u 2}$ indicates the need to take the unobserved heterogeneity into account. On the whole, these evidences support the adoption of the dynamic type-2 tobit model.

The first obvious result is the occurrence of persistence in innovation activity. As can be seen, the coefficients of the two lagged dependent variables are positive and highly significant in both equations and in all three models. This means that - even after controlling for individual unobserved heterogeneity, sectoral belonging and firm's characteristics - past innovative behaviour strongly affects both the current probability of engaging in R\&D activity and the current level of R\&D investment. However, both coefficients are smaller (by about 20\%) for the young firms and these differences turn out to be highly significant in both the equations (see the last column of Table 6). According to our hypothesis 4 (see Section 3), this outcome suggests that, owing to their lack of experience, young firms are less persistent in their innovative behaviour and that their innovative processes follow a more erratic path than that taken by their mature counterparts.

Apart from past innovative behaviour, other firm and market characteristics are found to be important $R \& D$ drivers.

Firstly, we turn our attention to the demand-pull theory. Indeed, the sign and significance of the DYNAM dummy variable suggest that favourable, expansive demand conditions are important factors both in increasing the probability of firms becoming R\&D performers and in increasing the amount of their innovative investment. This holds true for both mature and young firms. However, as can be seen, the coefficients are larger in the case of young firms, although - in this case - the differences are not statistically significant. This result weakly corroborates our hypothesis 1 , according to which newly created firms - due to their problems of liquidity constraints and credit rationing - are more sensitive to market prospects than

\footnotetext{
${ }^{14}$ The total cross-equation correlation (see eq. 6) is 0.23 for the full sample model, 0.25 for the mature firms and 0.25 for the young firms.
} 
their mature counterparts when deciding whether to engage in $R \& D$ and how much to invest.

This line of reasoning also applies to the outcome concerning the LEXP_1 variable: while in the selection equation its positive impact is obvious both for the mature and young firms; in the main equation its role is still positive and highly significant for the YICs, but appears not so relevant in the case of the mature firms ${ }^{15}$. Bearing in mind our hypothesis 2, this result can be seen as evidence that the level of exports - representing a fundamental component of demand evolution - plays an essential role in fuelling the innovation activity of firms that are more liquidity constrained, as is the case of theYICs. ${ }^{16}$

Conversely, a result that contrasts with expectations is our finding that young firms do not appear to be any more responsive to the amount of public subsidies received when determining how much to invest in R\&D activities. Although subsidies are associated with a higher probability of firms becoming R\&D performers in all three samples, the level of R\&D investment among young firms is not significantly affected by the amount of subsidies they receive in the previous period. These results, which run contrary to hypothesis 3, seem to suggest the need to design different policy measures to support the innovative activity of different cohorts of firms (i.e. young vs mature).

Turning our attention to the remaining results, the CONC variable appears to increases the probability of engaging in R\&D activities, but this relationship is statistically significant for the mature firms only. This is in line with our hypothesis 7 and confirms that only well established firms can take full advantage of market appropriability conditions.

A further result that is line with expectations (H5) is our finding that the DIVER regressor significantly increases a firm's probability of engaging in $R \& D$ only with reference to the mature firms. This outcome suggests that mature firms, thanks to their

\footnotetext{
${ }^{15}$ Although still positive, the coefficient is much lower and barely significant in the case of the mature firms; moreover, the difference between the estimated coefficient for the YICs and that for the larger firms is significant at the $99 \%$ level of confidence.

${ }^{16}$ This result is consistent with the outcome from a previous study (Pellegrino et al., 2011), indicating that exporting YICs are more likely to perform better in terms of innovative intensity.
} 
larger scale and greater experience, are more able to exploit the innovative benefits derived from scope economies.

Firms with more high-skilled workers are more likely both to engage in R\&D activities and to increase their amount of $R \& D$ investment. Interestingly enough, the results from the main equation support the proposed hypothesis 6, according to which YICs are expected to be more dependent on their own skill endowment ${ }^{17}$.

Finally, the "Schumpeterian hypothesis" turns out to be significantly and homogeneously confirmed by our empirical analysis: larger firms are more likely both to engage in $R \& D$ activities and to invest more in $R \& D$, and this is true both for the mature companies and for the YICs.

\section{Conclusions}

This paper has examined the determinants of R\&D activities using a large, representative sample of both young and mature Spanish manufacturing firms for the period 1990 to 2008. The econometric analysis conducted has used a recently proposed dynamic type-2 tobit model, jointly accounting for both individual effects and endogeneity and handling the initial condition and sample selection problems.

Importantly, both engagement in and the amount of investment in $R \& D$ present a very high degree of persistence over time. However, a lower degree of persistence is found in the innovative processes carried out within YICs. This could reflect the relative inexperience of such firms, resulting in a more erratic implementation of $R \& D$ projects.

Moreover, accordingly with our hypotheses, we found that market concentration and product diversification appear to increase the probability of engagement in $R \& D$ only in the case of the mature firms. By contrast, YICs are found to be more sensitive to 'demand-pull' factors, such as expansionary demand conditions and the amount of

${ }^{17}$ In fact, the correspondent coefficient for the YICs is significantly larger than the one associated to their mature counterparts (see the last column of Table 6). 
exports. This outcome is consistent with the hypothesis that young firms are likely to be more credit constrained and, as a result, more dependent on internal resources that are more closely correlated with the evolution in market demand. Finally, inexperienced YICs rely more on their skill endowments.

These results may have important implications. Indeed, based on our findings, policy makers should design their interventions on the understanding that different drivers may play distinct roles in boosting the innovation activity of firms of different age. 


\section{References}

Acs, Z.J., Audretsch, D.B., 1988. Innovation in large and small firms: an empirical analysis. American Economic Review 78, 678-690.

Acs, Z.J., Audretsch, D.B., 1990. Innovation and small firms. London: MIT Press.

Audretsch, D.B., 1997. Technological regimes, industrial demography and the evolution of industrial structures. Industrial and Corporate Change 6, 49-82.

Aghion, P., Howitt, P., 1998. Capital Accumulation and Innovation as Complementary Factors in Long-Run Growth. Journal of Economic Growth 3, 111-130.

Arrow, K.J., 1962. The economic implications of learning by doing. Review of Economic Studies 29, 155-173.

Artés, J., 2009. Long-run versus short-run decisions, R\&D and market structure in Spanish firms. Research Policy, 38, 120-132.

Atkinson, A.B., Stiglitz, J.E., 1969. A new view of technological change. Economic Journal 79, 573-578.

Bartelsman, E., Haltiwanger, J., Scarpetta, S., 2004. Microeconometric evidence of creative destruction in industrial and developing countries. IZA Discussion Paper No. 1374, Bonn.

Baumol, W. J., Litan R. E., Schramm, C. J., 2007. Good Capitalism, Bad Capitalism. New Haven: Yale University Press.

Beck, T., Demirgüç-Kunt, A., 2006. Small and Medium-Size Enterprises. Access to Finance as Growth Constraint. Journal of Banking and Finance 30, 2931-2943.

Berger, A., Udell, G., 2002. Small business credit availability and relationship lending: the importance of bank organizational structure. Economic Journal 112, 32-53.

Blundell, R., Griffith, R., Van Reenen, J., 1999. Market share, market value and innovation in a panel of British manufacturing firms. Review of Economic Studies 66, 529-554.

Brouwer, E., Kleinknecht, A., 1996. Firm size, small business presence and sales in innovative products: a micro-econometric analysis. Small Business Economics 8, 189-201.

Brouwer, E., Kleinknecht, A., 1999. Keynes-plus? Effective demand and changes in firm-level R\&D: an empirical note. Cambridge Journal of Economics 23, 385-391.

Callejon, M., García-Quevedo, J., 2005. Public Subsidies to Business R\&D: Do they Stimulate Private Expenditures? Environment and Planning C: Government and Policy 23, 279-293.

Cassiman, B., Golovko E., Martinez-Rios E., 2010. Innovation, export and productivity. International Journal of Industrial Organization 28, 372-376.

Cincera, M., 2003. Financing constraints, fixed capital and R\&D investment decisions of Belgian firms, in Butzen, P., Fuss, C. (eds.), Firms' Investment and Finance Decisions: Theory and Empirical Methodology, Cheltenham, United Kingdom: Edward Elgar Publishing, 129-147. 
Clerides, S.K., Lach, S., Tybout, J.R., 1998. Is learning by exporting important? Micro-dynamic evidence from Colombia, Mexico and Morocco. Quarterly Journal of Economics 113, 903-947.

Cohen, W.M., Levinthal, D. A., 1989. Innovation and learning: the two faces of R\&D - implications for the analysis of R\&D investment. Economic Journal 99, 569596.

Cohen, W.M., Levinthal, D.A., 1990. Absorptive capacity: a new perspective on learning and innovation. Administrative Science Quarterly 35, 128-152.

Cohen, W.M., Klepper, S., 1996. A reprise of size and R\&D. Economic Journal 106, 925-951.

Conte, A., Vivarelli, M., 2005. One or many knowledge production functions? Mapping innovative activity using microdata, IZA Discussion Paper No. 1878, Bonn.

Crepon, B., Duguet, E., Mairesse, J., 1998. Research, innovation and productivity: an econometric analysis at the firm level. Economics of Innovation and New Technology 7, 115-158.

Czarnitzki D., Hottenrott, H., 2011. R\&D investment and financing constraints of small and medium-sized firms. Small Business Economics 36, 65-83.

Czarnitzki, D., 2006. Research and development in small- and medium-sized enterprises: The role of financial constraints and public funding. Scottish Journal of Political Economy 53, 257-335.

David, P., 1985. Clio and the economics of QWERTY. American Economic Review Proceedings 75, 332-337.

Dosi, G., 1988. Sources, procedures, and microeconomic effects of innovation. Journal of Economic Literature 26, 1120-1171.

Dosi, G. 1997. Opportunities, Incentives and the Collective Patterns of Technological Change, Economic Journal, 107, 1530-1547

EC-DG ENTR 2009. European Competitiveness Report 2008, Luxemburg.

Fluck, Z, Holtz-Eakin, D., Rosen, H., 1997. Where Does the Money Come From? An Empirical Investigation of Small Entrepreneurial Enterprises. Syracuse University. Metropolitan Studies Program Series Occasional Paper No. 191, Princeton University.

Fritsch, M., Brixy, U. and Falck, O., 2006. The Effect of Industry, Region and Time on New Business Survival - A Multi-Dimensional Analysis. Review of Industrial Organization 28, 285-306.

Geroski, P., Walters, C.F., 1995. Innovative activity over the business cycle. Economic Journal 105, 916-928.

Gilbert, R., Newbery, D., 1982. Preemptive patenting and the persistence of monopoly. American Economic Review 72, 514-526.

González, X., Jaumandreu, J., Pazó, C., 2005. Barriers to Innovation and Subsidy Effectiveness. Rand Journal of Economics 36, 930-949. 
Goodacre, A., Tonks, I., 1995. Finance and technological change. 298-341 in Stoneman, P. (eds.), Handbook of the Economics of Innovation and Technical Change, Oxford, Blackwell.

Griliches, Z., 1979. Issues in assessing the contribution of research and development to productivity growth. Bell Journal of Economics 10, 92-116.

Griliches, Z., 1994. Productivity, R\&D, and the Data Constraint. American Economic Review 84, 1-23.

Griliches, Z., 1996. R\&D and Productivity: The Unfinished Business, in Griliches, Z. (ed.) 1998, R\&D and Productivity: The Econometric Evidence, Chicago and London, University of Chicago Press, 269-283.

Hall, B. H., 2008. The financing of innovation. 409-430 in Shane, S. (eds.), Blackwell Handbook of Technology and Innovation Management. Blackwell Publishers, Ltd Oxford.

Hall, B., Mairesse, J., Branstetter, L. and Crépon, B., 1999. Does cash flow cause investment and R\&D? An exploration using panel data for French, Japanese, and United States scientific firms, in Audretsch, D., Thurik, R. (eds.), Innovation, Industry Evolution and Employment, Cambridge, Cambridge University Press, 129-56

Henderson, R., Cockburn, I., 1996. Scale, scope, and spillovers: the determinants of research productivity in drug discovery. RAND Journal of Economics 27, 32-59.

Kleinknecht, A., Verspagen, B., 1990. Demand and innovation: Schmookler reexamined. Research Policy 19, 387-394.

Klevorick, A.K., Levin, R.C., Nelson, R.R., Winter, S.G., 1995. On the sources and significance of interindustry differences in technological opportunities. Research Policy 24, 185-205.

Lopez, A., 2008. Determinants for R\&D cooperation: Evidence from Spanish manufacturing firms. International Journal of Industrial Organization 26, 113-136.

Lucas, R. J., 2002. Lectures on Economic Growth. Camdridge, Massachusetts: Harvard University Press.

Mairesse, J., Mohnen, P., 2002. Accounting for innovation and measuring innovativeness: an illustrative framework and an application. American Economic Review, Papers and Proceedings 92, 226-230.

Mankiw, N.G., Romer, D., Weil, D.N., 1992. A contribution to the empirics of economic growth. Quarterly Journal of Economics 107, 407-437.

Mansfield, E., 1988. Industrial R\&D in Japan and the United States: a comparative study. American Economic Review 78, 223-228.

Martinelli, C., 1997. Small firms, borrowing constraints, and reputation. Journal of Economic Behavior and Organization 33, 91-105.

Melitz, M., 2003. The impact of trade on aggregate industry productivity and intraindustry reallocations. Econometrica 71, 1695-1725.

Mohnen, P., Dagenais, M., 2002. Towards an innovation intensity index. The case of CIS-I in Denmark and Ireland, in Kleinknecht, A., Mohnen, P. (eds.), Innovation and 
Firm Performance. Econometric Explorations of Survey Data. P. Palgrave, New York, 3-30.

Mowery, D.C., 1983. Economic-theory and government technology policy. Policy Sciences 16, 27-43.

Mowery, D.C., Rosenberg, N., 1979. The influence of market demand upon innovation: a critical review of some recent empirical studies. Research Policy 8, 102153.

Mundlak, Y., 1978. On the pooling of time series and cross section data. Econometrica 46, 69-85.

Nelson, R.R., Winter, S., 1982. An Evolutionary Theory of Economic Change. Cambridge, Massachusetts, Belknap Press of Harvard University Press.

Ortega-Argilés, R., Moreno, R., Suriñach Caralt, J., 2005. Ownership structure and innovation: is there a real link? Annals of Regional Science 39, 637-662.

O’Sullivan, M., 2005. Finance and innovation. in Fagerberg, J., Mowery, D. C., Nelson, R. R. (eds.), The Oxford Handbook of Innovation, Oxford: Oxford University Press, 240-265.

Pavitt, K., 1984. Sectoral patterns of technical change - towards a taxonomy and a theory. Research Policy 13, 343-373.

Pellegrino, G., Piva, M., Vivarelli, M., 2011. Young firms and innovation: a microeconometric analysis. Structural Change and Economic Dynamics, forthcoming.

Petersen, M., Rajan, R., 1995. The effect of credit market competition on lending relationships: Evidence from small business data. Journal of Finance 49, 3-37.

Piva, M., Vivarelli, M., 2007. Is demand-pulled innovation equally important in different groups of firms? Cambridge Journal of Economics 31, 691-710.

Piva, M., Vivarelli, M., 2009. The role of skills as a major driver of corporate R\&D. International Journal of Manpower 30, 835-852.

Raymond, W., Mohnen, P., Palm, F., Schim van der Loeff, S., 2010. Persistence of Innovation in Dutch manufacturing: Is it Spurious? Review of Economics and Statistics 92, 495-504.

Reid, G.C., 2003. Trajectories of small business financial structure. Small Business Economics 20, 273-285.

Romer, P.M., 1994. The origins of endogenous growth. Journal of Economic Perspectives 8, 3-22.

Rosenberg, N., 1982. Inside the Black Box: Technology and Economics. Cambridge University Press, Cambridge.

Rosenberg, N., 1990. Why do firms do basic research with their own money? Research Policy 19, 165-174.

Rosenberg, N., 1994. Exploring the Black Box: Technology, Economics, and History. Cambridge University Press, Cambridge.

Santarelli, E., Vivarelli, M., 2007. Entrepreneurship and the process of firms' entry, survival and growth. Industrial and Corporate Change 16, 455-488. 
Scherer, F. M., 1982. Demand-pull and technological invention: Schmookler revisited. Journal of Industrial Economics 30, 225-237.

Schmookler, J. 1962. Economic sources of inventive activity. Journal of Economic History 22, 1-10.

Schmookler, J., 1966. Invention and Economic Growth, Cambridge, MA, Harvard University Press.

Schneider, C., Veugelers, R., 2010. On young highly innovative companies: why they matter and how (not) to policy support them. Industrial and Corporate Change 19, 969-1007.

Schumpeter, J.A., 1942. Capitalism, Socialism and Democracy. Harper and Brothers, New York.

Song, J., Almeida, P., Wu, G., 2003. Learning-by-hiring: when is mobility more likely to facilitate interfirm knowledge transfer? Management Science 49, 351-365.

Wallsten, S.J., 2000. The effects of government-industry R\&D programs on private R\&D: the case of the Small Business Innovation Research Program. RAND Journal of Economics 31, 82-100.

Wooldridge, J.M., 2005. Simple Solutions to the Initial Conditions Problem in Dynamic, Nonlinear Panel Data Models with Unobserved Heterogeneity. Journal of Applied Econometrics 20, 39-54.

Yeaple, S.R., 2005. A simple model of firm heterogeneity, international trade and wages. Journal of International Economics 65, 1-20. 
Table 1. Composition of the panel

\begin{tabular}{|c|c|c|c|c|}
\hline Time obs. & $\mathrm{N}^{\mathrm{o}}$ of firms & $\%$ & Cum. \% & $\mathrm{N}^{\mathrm{o}}$ of obs. \\
\hline 1 & 505 & 14.47 & 14.47 & 505 \\
\hline 2 & 540 & 15.48 & 29.95 & 1,080 \\
\hline 3 & 625 & 17.91 & 47.86 & 1,875 \\
\hline 4 & 192 & 5.50 & 53.37 & 768 \\
\hline 5 & 192 & 5.50 & 58.87 & 960 \\
\hline 6 & 238 & 6.82 & 65.69 & 1,428 \\
\hline 7 & 135 & 3.87 & 69.56 & 945 \\
\hline 8 & 60 & 1.72 & 71.28 & 480 \\
\hline 9 & 133 & 3.81 & 75.09 & 1,197 \\
\hline 10 & 50 & 1.43 & 76.53 & 500 \\
\hline 11 & 130 & 3.73 & 80.25 & 1,430 \\
\hline 12 & 70 & 2.01 & 82.26 & 840 \\
\hline 13 & 69 & 1.98 & 84.24 & 897 \\
\hline 14 & 95 & 2.72 & 86.96 & 1,330 \\
\hline 15 & 110 & 3.15 & 90.11 & 1,650 \\
\hline 16 & 44 & 1.26 & 91.37 & 704 \\
\hline 17 & 301 & 8.63 & 100.00 & 5,117 \\
\hline Total & 3,489 & 100.00 & & 21,706 \\
\hline \multicolumn{5}{|c|}{$\begin{array}{l}\text { Note: the final sample only comprises firms for which a lag of the } \\
\text { dependent variable is available. This implies that } t=1 \text { refers to } \\
\text { firms that are observed for at least two periods, } t=2 \text { corresponds to } \\
\text { firms that are observed for three periods and so on. }\end{array}$} \\
\hline
\end{tabular}


Table 2. Sample size according to age threshold and innovative status

\begin{tabular}{lcccccc}
\hline \hline & \multicolumn{2}{c}{ ALL FIRMS } & \multicolumn{2}{c}{ MATURE } & \multicolumn{2}{c}{ YOUNG } \\
& $N^{o}$ of firms & $N^{o}$ of obs. & $N^{o}$ of firms & $N^{o}$ of obs. & $N^{o}$ of firms & $N^{o}$ of obs. \\
\hline \multirow{2}{*}{ No $R \& D$} & 2,333 & 14,535 & 1,414 & 11,384 & 919 & 3,151 \\
& $(66.87)$ & $(66.96)$ & $(60.92)$ & $(64.28)$ & $(78.68)$ & $(78.87)$ \\
\multirow{4}{*}{$R \& D$} & 1,156 & 7,171 & 907 & 6,327 & 249 & 844 \\
\multirow{2}{*}{ Total } & $(33.13)$ & $(33.04)$ & $(39.08)$ & $(35.72)$ & $(21.32)$ & $(21.13)$ \\
& 3,489 & 21,706 & 2,321 & 17,711 & 1,168 & 3,995 \\
& $(100)$ & $(100)$ & $(66.52)$ & $(81.59)$ & $(33.48)$ & $(18.41)$ \\
\hline \multicolumn{2}{l}{ Note: percentages in brackets. }
\end{tabular}

Table 3. Transition probabilities of innovator status

\begin{tabular}{cccc}
\hline \hline & & $N o R \& D$ & $R \& D$ \\
\hline \multirow{2}{*}{ ALL FIRMS } & No $R \& D$ & 94.23 & 5.77 \\
& $R \& D$ & 12.17 & 87.83 \\
\hline \multirow{2}{*}{ MATURE } & No $R \& D$ & 93.98 & 6.02 \\
& $R \& D$ & 11.24 & 88.76 \\
\hline \multirow{2}{*}{ YOUNG } & No $R \& D$ & 94.81 & 5.19 \\
& $R \& D$ & 19.36 & 80.64 \\
\hline \hline
\end{tabular}


Table 4. Descriptive statistics: mean and standard deviation (overall, between and within) of the variables; all firms - mature firms - young firms

\begin{tabular}{|c|c|c|c|c|c|c|c|c|c|c|c|c|}
\hline & \multicolumn{4}{|c|}{ ALL FIRMS } & \multicolumn{4}{|c|}{ MATURE } & \multicolumn{4}{|c|}{ YOUNG } \\
\hline & \multirow[t]{2}{*}{ Mean } & \multicolumn{3}{|c|}{ Std. Dev. } & \multirow[t]{2}{*}{ Mean } & \multicolumn{3}{|c|}{ Std. Dev. } & \multirow[t]{2}{*}{ Mean } & \multicolumn{3}{|c|}{ Std. Dev. } \\
\hline & & Overall & Between & Within & & Overall & Between & Within & & Overall & Between & Within \\
\hline RD_d & 0.330 & 0.470 & 0.426 & 0.234 & 0.357 & 0.479 & 0.435 & 0.234 & 0.211 & 0.408 & 0.372 & 0.191 \\
\hline LRD & 1.677 & 2.666 & 2.545 & 1.080 & 1.855 & 2.766 & 2.618 & 1.113 & 0.889 & 1.979 & 1.968 & 0.703 \\
\hline CONC & 0.557 & 0.497 & 0.418 & 0.314 & 0.573 & 0.495 & 0.422 & 0.304 & 0.484 & 0.500 & 0.435 & 0.283 \\
\hline DIVER & 0.142 & 0.349 & 0.306 & 0.208 & 0.141 & 0.348 & 0.310 & 0.200 & 0.143 & 0.351 & 0.313 & 0.181 \\
\hline DYNAM & 0.251 & 0.433 & 0.301 & 0.350 & 0.244 & 0.430 & 0.303 & 0.344 & 0.280 & 0.449 & 0.341 & 0.316 \\
\hline LEXP_1 & 4.190 & 4.076 & 3.935 & 1.293 & 4.567 & 4.101 & 3.967 & 1.265 & 2.519 & 3.505 & 3.399 & 1.059 \\
\hline LSUB_1 & 0.506 & 1.726 & 1.372 & 1.095 & 0.558 & 1.807 & 1.446 & 1.136 & 0.274 & 1.280 & 1.023 & 0.739 \\
\hline SKILL & 4.169 & 6.810 & 6.905 & 2.991 & 4.396 & 6.852 & 7.125 & 2.921 & 3.163 & 6.530 & 6.433 & 2.475 \\
\hline LEMP & 4.112 & 1.435 & 1.432 & 0.235 & 4.248 & 1.447 & 1.430 & 0.221 & 3.510 & 1.210 & 1.233 & 0.199 \\
\hline Obs & \multicolumn{4}{|c|}{21,706} & \multicolumn{4}{|c|}{17,771} & \multicolumn{4}{|c|}{3,995} \\
\hline
\end{tabular}


Table 5. Sectoral composition (2-digit manufacturing sector) and average employment for mature and young firms

\begin{tabular}{|c|c|c|c|c|c|c|}
\hline \multirow[b]{2}{*}{ INDUSTRY } & \multicolumn{3}{|c|}{ YOUNG } & \multicolumn{3}{|c|}{ MATURE } \\
\hline & $\begin{array}{l}\text { N. of } \\
\text { Obs. }\end{array}$ & $\%$ & $\begin{array}{c}A v . \\
\text { Emp. }\end{array}$ & $\begin{array}{l}\text { N. of } \\
\text { Obs. }\end{array}$ & $\%$ & $\begin{array}{l}\text { Av. } \\
\text { Emp. }\end{array}$ \\
\hline Meat products & 112 & 2.8 & 86 & 559 & 3.2 & 223 \\
\hline Food and tobacco & 340 & 8.5 & 85 & 1,833 & 10.4 & 211 \\
\hline Beverage & 34 & 0.9 & 56 & 367 & 2.1 & 255 \\
\hline Textiles and clothing & 470 & 11.8 & 54 & 1,763 & 10.0 & 141 \\
\hline Leather, fur and footwear & 172 & 4.3 & 21 & 480 & 2.7 & 47 \\
\hline Timber & 203 & 5.1 & 48 & 467 & 2.6 & 101 \\
\hline Paper & 100 & 2.5 & 129 & 508 & 2.9 & 169 \\
\hline Printing & 268 & 6.7 & 27 & 910 & 5.1 & 142 \\
\hline Chemicals and pharmaceuticals & 152 & 3.8 & 279 & 1,252 & 7.1 & 263 \\
\hline Plastic and rubber products & 270 & 6.8 & 102 & 930 & 5.3 & 176 \\
\hline Non-metal mineral products & 251 & 6.3 & 80 & 1,260 & 7.1 & 151 \\
\hline Basic metal products & 97 & 2.4 & 277 & 634 & 3.6 & 462 \\
\hline Fabricated metal products & 456 & 11.4 & 36 & 1,771 & 10.0 & 118 \\
\hline Machinery and equipment & 233 & 5.8 & 72 & 1,275 & 7.2 & 190 \\
\hline Computer products, electronics and optical & 46 & 1.2 & 230 & 261 & 1.5 & 242 \\
\hline Electric materials and accessories & 214 & 5.4 & 181 & 930 & 5.3 & 238 \\
\hline Vehicles and accessories & 139 & 3.5 & 566 & 858 & 4.8 & 920 \\
\hline Other transport equipment & 44 & 1.1 & 453 & 370 & 2.1 & 763 \\
\hline Furniture & 306 & 7.7 & 37 & 882 & 5.0 & 94 \\
\hline Other manufacturing & 88 & 2.2 & 28 & 401 & 2.3 & 88 \\
\hline SAMPLE & 3,995 & 100.0 & 103 & 17,711 & 100.0 & 228 \\
\hline
\end{tabular}


Table 6. Results from the dynamic type 2 tobit estimates

\begin{tabular}{|c|c|c|c|c|c|c|c|c|}
\hline \multirow[b]{2}{*}{ RD_d_1 } & \multicolumn{2}{|c|}{ TOTAL } & \multicolumn{2}{|c|}{ MATURE } & \multicolumn{2}{|c|}{ YOUNG } & \multicolumn{2}{|c|}{$\begin{array}{c}\text { Diff. Mature vs } \\
\text { Young }\end{array}$} \\
\hline & $1.911^{* * *}$ & $(48.83)$ & $1.998 * * *$ & $(46.65)$ & $1.635^{* * *}$ & $(13.61)$ & $0.363 * * *$ & $(2.84)$ \\
\hline CONC & $0.091 * * *$ & $(2.71)$ & $0.090 * *$ & $(2.42)$ & 0.109 & $(1.44)$ & -0.019 & $(-0.22)$ \\
\hline DIVER & $0.106^{* *}$ & $(2.38)$ & 0.095* & $(1.92)$ & 0.121 & $(1.20)$ & -0.026 & $(-0.23)$ \\
\hline DYNAM & $0.158 * * *$ & $(4.54)$ & $0.151^{* * *}$ & (3.89) & $0.201^{* * *}$ & $(2.59)$ & -0.050 & $(-0.58)$ \\
\hline LEXP_1 & $0.047 * * *$ & $(7.89)$ & $0.048^{* * *}$ & $(7.32)$ & $0.039 * * *$ & $(2.86)$ & 0.009 & $(0.57)$ \\
\hline LSUB_1 & $0.055^{* * * *}$ & $(4.86)$ & $0.050 * * *$ & $(4.13)$ & $0.097 * * *$ & $(2.90)$ & -0.047 & $(-1.33)$ \\
\hline SKILL & $0.014^{* * *}$ & $(4.98)$ & $0.014^{* * *}$ & $(4.69)$ & $0.011^{*}$ & $(1.84)$ & 0.004 & $(0.55)$ \\
\hline LEMP & $0.204 * * *$ & $(11.05)$ & $0.201 * * *$ & $(9.82)$ & $0.181^{* * *}$ & $(4.13)$ & 0.019 & $(0.39)$ \\
\hline INTERCEPT & $-3.074 * * *$ & $(-20.90)$ & $-3.004^{* * *}$ & $(-18.39)$ & $-3.314^{* * *}$ & $(-8.58)$ & 0.310 & $(0.74)$ \\
\hline $\mathrm{N}^{\circ}$ of firms & \multicolumn{2}{|c|}{21,706} & \multicolumn{2}{|c|}{17,711} & \multicolumn{2}{|c|}{3,995} & \multicolumn{2}{|c|}{-} \\
\hline \multicolumn{9}{|l|}{ MAIN EQUATION } \\
\hline LRD_1 & $0.297 * * *$ & $(33.96)$ & $0.302^{* * *}$ & $(32.64)$ & $0.242^{* * *}$ & $(8.35)$ & $0.060 * *$ & (1.99) \\
\hline DYNAM & $0.078 * * *$ & $(2.89)$ & $0.077 * * *$ & $(2.71)$ & $0.178 * *$ & $(2.22)$ & -0.100 & $(-1.18)$ \\
\hline LEXP_1 & $0.017 * * *$ & $(3.02)$ & $0.011^{*}$ & $(1.84)$ & $0.062^{* * *}$ & $(3.48)$ & $-0.051^{* * *}$ & $(-2.73)$ \\
\hline LSUB_1 & $0.035^{* * *}$ & (6.26) & $0.037 * * *$ & $(6.45)$ & 0.028 & $(1.56)$ & 0.009 & $(0.47)$ \\
\hline SKILL & $0.025^{* * *}$ & $(10.00)$ & $0.023^{* * *}$ & $(8.87)$ & $0.038^{* * *}$ & $(5.31)$ & $-0.015^{* *}$ & $(-1.97)$ \\
\hline LEMP & $0.602 * * *$ & $(32.71)$ & $0.615^{* * *}$ & $(30.61)$ & $0.545^{* * *}$ & $(11.71)$ & 0.070 & (1.39) \\
\hline INTERCEPT & $-0.722 * * *$ & $(-5.39)$ & $-0.825^{* * *}$ & $(-5.85)$ & -0.581 & $(-0.91)$ & -0.245 & $(-0.37)$ \\
\hline $\mathrm{N}^{\mathrm{o}}$ of Obs. & \multicolumn{2}{|c|}{7,171} & \multicolumn{2}{|c|}{6,327} & \multicolumn{2}{|c|}{844} & \multicolumn{2}{|c|}{-} \\
\hline \multicolumn{9}{|c|}{ EXTRA PARAMETERS } \\
\hline Init.cond. (RD_d) & $0.662^{* * *}$ & $(12.27)$ & $0.623^{* * *}$ & $(10.83)$ & $0.747 * * *$ & $(4.61)$ & - & - \\
\hline Init.cond. (LRD) & $0.062 * * *$ & $(8.51)$ & $0.058 * * *$ & $(7.44)$ & $0.062^{* * *}$ & $(2.66)$ & - & - \\
\hline$\rho_{\mathrm{u} 1 \mathrm{u} 2}$ & $0.414^{* * *}$ & $(14.25)$ & $0.432 * * *$ & $(14.12)$ & $0.404^{* * *}$ & $(4.01)$ & - & - \\
\hline$\rho_{\varepsilon 1 \varepsilon 2}$ & $0.161^{* * *}$ & $(3.82)$ & $0.180^{* * *}$ & $(4.15)$ & 0.102 & $(0.82)$ & - & - \\
\hline$\sigma_{\mathrm{u} 1}$ & $-0.755^{* * *}$ & $(-12.28)$ & $-0.795^{* * *}$ & $(-10.89)$ & $-0.935^{* * *}$ & $(-2.84)$ & - & - \\
\hline$\sigma_{\mathrm{u} 2}$ & $-0.664 * * *$ & $(-21.07)$ & $-0.685^{* * *}$ & $(-19.94)$ & $-0.430 * * *$ & $(-5.48)$ & - & - \\
\hline$\sigma_{\varepsilon 2}$ & $-0.072 * * *$ & $(-7.51)$ & $-0.079 * * *$ & $(-7.74)$ & $-0.102^{* * *}$ & $(-3.14)$ & - & - \\
\hline
\end{tabular}

t- statistics in brackets: * Significant at $10 \% ; * * 5 \% ; * * * 1 \%$

All regressions include time and industries dummies (results available upon request). 


\section{Appendix}

Table A1. The variables: acronyms and definitions.

\section{Dependent Variables}

RD_d Dummy $=1$ if firm’s R\&D expenditures are positive

LRD Log of firm's total R\&D expenditures (the cost of intramural R\&D activities and payments for outside R\&D contracts)

Explanatory variables

CONC Dummy $=1$ if the firm reports that its main market consists of 10 dominant firms or less; 0 otherwise

DIVER Dummy=1 if the firm is characterised by product diversification; 0 otherwise

DYNAM Dummy $=1$ if the firm reports that its main market is expansive; 0 if it is stable or recessionary

LEXP Log of the total amount of exports

LSUB Log of the total amount of public funding received by the firm

SKILL Ratio of engineers and graduates over total employment

LEMP Log of the total number of firm's employees

Table A2. Correlation between the explanatory variables and their corresponding Mundlak means

\begin{tabular}{ll}
\hline \hline CONC & 0.76 \\
DIVER & 0.79 \\
DYNAM & 0.57 \\
LEXP_1 & 0.95 \\
LSUB_1 & 0.77 \\
SKILL & 0.90 \\
LEMP & 0.99 \\
\hline \hline
\end{tabular}

